\title{
The Promise of Property: Legal Optimism and Collective Efficacy in Chicago's Urban Agriculture District
}

\author{
Nate Ela
}

[As accepted by Social Problems, 16 November 2019]

\begin{abstract}
Studies of legal cynicism have documented the reluctance of residents in lowincome minority neighborhoods to call on criminal law and the police. But are people in such places equally cynical about other forms of law? This article explains how and why community organizers in Chicago's Englewood neighborhood have found promise in the opportunities that institutions of property provide for addressing community problems. Drawing on interviews and ethnographic fieldwork, it examines the creation of neighborhood institutions for Chicago's first urban agriculture district. These institutions have been informed by memories of slavery and sharecropping, and of the role played by food production and economic cooperation in struggles for African American self-determination. To keep ownership, use, and benefits of urban farmland local, organizers in Englewood founded a community land trust. They view this new neighborhood institution as a way to cultivate a sense of community ownership and control, and thereby chip away at the alienation that blocks residents from addressing local problems. Prior studies have linked collective efficacy and residents' individual sense of ownership; the experience in Englewood points to how collective efficacy could also be fostered by institutions that demonstrate collective, African-American ownership of community resources. The article concludes by discussing why organizers and residents in race-class subjugated communities may find promise in, but also limits to, the sense of sovereignty and legal agency afforded by property.
\end{abstract}


Over the past twenty years, urban sociologists have found that residents of neighborhoods characterized by concentrated disadvantage tend to be more cynical toward law and its potential to solve local problems than people living in other places. Legal cynicism, a concept initially proposed to describe a place-based sense of moral anomie (Sampson and Bartusch 1998), has motivated a productive series of studies into the causes and consequences of residents' reluctance to call on law to solve community problems. These have found, among other things, that legal cynicism is associated with higher homicide rates (Kirk and Papachristos 2011), and a reduced likelihood of crimes leading to arrests (Kirk and Matsuda 2011).

Neighborhood-level findings concerning legal cynicism, however, have a key limitation: while aspiring to explain attitudes toward law writ large, they have focused on residents' attitudes toward criminal law and its enforcers (e.g. Kirk and Papachristos 2011; Kirk 2016; Bell 2016). To be sure, police and criminal law affect the lives of poor and minority residents in significant and painfully unavoidable ways. Yet neighborhoods of concentrated disadvantage, like any other place, are shaped by many forms of law other than criminal law. Sociolegal scholars have only recently begun to explore the dynamics of legal cynicism with respect to immigration law and civil rights (Ryo 2016; McElhattan et al. 2017). We still know remarkably little, however, about attitudes in urban neighborhoods toward legal institutions and actors beyond criminal law and the police. In the types of places where sociologists have found high rates of cynicism vis-à-vis criminal law, are people also cynical toward other legal institutions?

This article offers a first step toward a place-based understanding of the dynamics of legal cynicism beyond criminal law. It does so by returning to one of the neighborhoods on Chicago's South Side that originally prompted sociologists to coin the concept of legal cynicism, and developing a case study of a project to develop a new local property institution: a community land trust designed to ensure community control over urban farmland. This case study reveals that local property institutions - particularly those that demonstrate community ownership and control over neighborhood resources - can cultivate a sense of legal optimism.

These findings emerge from interviews with people involved in designing the institutions of Chicago's first urban agriculture district. In 2015, Chicago's City Council approved a plan that designated parts of the South Side neighborhood of Englewood as an urban agriculture district. This prompted a series of discussions among community organizers, city planners, and urban growers, focused on the question of what entity should own and manage the use of urban farmland in this poor and almost entirely African-American neighborhood. The article traces how African-American growers and community organizers grappled with the question of what sort of institution should own and manage urban farmland, and why some decided to create a Black-led community land trust. Part of the reason organizers perceived promise in this new local property institution, the article concludes, was 
its potential to instill in residents a sense of ownership and control over a key neighborhood resource.

Here, the article identifies a new connection between local property institutions and collective efficacy. Previous studies have found that collective efficacy is positively associated with individual homeownership (Sampson 2012), and with the sense of ownership that gardening instills in renters (Walton 2016). These studies suggest that individual ownership, or simply a sense of ownership, helps foster neighborhood collective efficacy. The findings here suggest property institutions that demonstrate collective ownership and control over community resources could also encourage residents to feel more invested in solving community problems, and thereby increase neighborhood collective efficacy.

Looking beyond criminal law opens up new terrain for studying legal cynicism and collective efficacy in neighborhood contexts. After presenting findings from the case study, the article discusses reasons why local property institutions, in contrast with the institutions and agents of criminal law, could be more likely to foster legal optimism and collective efficacy. As a form of private law, property permits people to act directly as legal agents, and develop local institutions rather than relying entirely on state officials. Residents are more likely to feel they are working with legal institutions, rather than against them (Ewick and Silbey 1998). Property ownership also affords a sense of sovereignty (Cohen 1927), and protection from interference by the state. Nevertheless, the success of new local property institutions can turn on support from state officials. This suggests that, should state officials fail to endorse local efforts to promote community ownership, a nascent sense of promise instilled by new property institutions could slip into a renewed sense of legal cynicism.

\section{LEGAL CYNICISM BEYOND CRIMINAL LAW}

Sampson and Bartusch (1998) initially proposed the concept of legal cynicism to help account for a place-based sense of moral anomie. In taking up the concept, later studies focused on attitudes toward criminal law and its enforcers (Kirk and Papachristos 2011; Bell 2016; Kirk 2016). This article extends recent efforts to understand legal cynicism beyond criminal law, by returning to the setting in which the concept was developed.

Scholars have sought to understand the causes and consequences of legal cynicism. Sampson and Bartusch $(1998,789,798)$ found that settings of "concentrated disadvantage" - high rates of poverty, public assistance, unemployment, female-headed households, minors, and African-American residents - have higher levels of legal cynicism. Kirk and Papchristos (2011) interpreted this cynicism as a cultural adaptation to a neighborhood's structural 
conditions. Some residents may act strategically, such as the mothers who Bell (2016) observed calling particular police officers in some situations, but not others. Scholars have proposed reducing cynicism by using procedural reforms to bolster the criminal justice system's legitimacy (Tyler et al. 2013), or by addressing the structural roots of its historic injustices (Bell 2017).

Scholars have begun to examine legal cynicism beyond urban neighborhoods, and beyond criminal law. The apparent arbitrariness of immigration law, Ryo $(2016,120)$ found, can foster cynicism among immigrant detainees. In the context of civil rights, McElhattan, Nielsen, and Weinberg (2017) found that African Americans and Latinos were actually more likely than whites to express confidence in litigation as a remedy for workplace discrimination.

Life in urban neighborhoods, of course, is also shaped by more than just criminal law. Private law, particularly property and contract, have produced and maintained racial inequality (Satter 2009; Coates 2014; Rothstein 2017). Landlordtenant disputes are governed by rules tilted in owners' favor, contributing to an ongoing eviction crisis (Desmond 2016). Real estate contracts, even when judicially unenforceable, perpetuate neighborhood segregation (Brooks and Rose 2013). Private law has contributed to producing race-class subjugated communities (Soss and Weaver 2017), and the demographic features known as "concentrated disadvantage."

How do community organizers assess the institutions of private law that shape neighborhoods? Where do they perceive promise, and strategic opportunities? What possibilities do the institutions of private law offer, that those of criminal law do not? This article returns to one of the neighborhoods that prompted Sampson and Bartusch (1998) to develop the concept of legal cynicism, to understand why and how organizers are trying to rework neighborhood institutions.

\section{PROPERTY AND COLLECTIVE EFFICACY}

Neighborhood property institutions point to a new link between legal cynicism and collective efficacy. Scholars have previously examined how collective efficacy - a combination of "mutual trust and the willingness to intervene for the common good" (Sampson et al. 1997, 919) - relates to cynicism toward criminal law and policing (Kirk and Matsuda 2011; Sampson 2012). Existing research supports the intuition that people who feel a sense of ownership would be more willing to address community problems. Homeownership rates and residential stability are associated with higher collective efficacy (Sampson 2012, 154). The sense of ownership that renters can feel from growing gardens can also foster collective efficacy (Walton 2016). Sampson has suggested, anecdotally, that 
property-related community organizing - a campaign by Englewood residents to resist the use of eminent domain to expand a railyard - could mark a "potential turning point where things build upon themselves in a positive way." (Guarino 2013)

This study responds to calls for a better understanding of neighborhood institutions (Allard and Small 2013; Marwell and McQuarrie 2013) in two ways. First, it asks how collective efficacy relates to the institutions of property that structure life for residents (North 1991). This contrasts with studies that have interpreted organizations and places - such as schools, churches, and parks - as neighborhood institutions (Small and Newman 2001, 33).

Second, rather than taking neighborhood institutions as fixed, it asks how and why organizers work to create new ones. One possibility is that new institutions foster collective efficacy by reducing resource deprivation. This would fit with the suggestion by Sampson and his coauthors that "the alienation, exploitation, and dependency wrought by resource deprivation act as a centrifugal force that stymies collective efficacy." (Sampson et al. 1997, 919) Another possibility is that local property institutions foster collective efficacy because they impart a sense of ownership and control over existing resources. Rather than simply increasing resources, the key mechanism would instead be demonstrating legal power. The article traces connections organizers are making between ownership, empowerment, and collective efficacy. In doing so, it reveals parallels between contemporary institutional strategies and past projects linking African-American ownership and empowerment. ${ }^{1}$

\section{METHODS AND DATA}

This article presents the results of an ethnographic revisit (Burawoy 2003) to neighborhoods on Chicago's South Side that have repeatedly drawn sociologists' attention. It was here that Wilson (1996) examined how residents coped when deindustrialization caused work to disappear. "One of my main top concerns," an outraged South Side woman told Wilson's team, "[is that] on your South and West Sides, you see all these vacant lots." (Id. 3-4) When Raudenbush and Sampson $(2002,8)$ analyzed the features of these landscapes that favored collective efficacy, they interpreted vacancy as a sign of social disorder.

This case study examined a project to transform the vacant lots that residents, scholars, and city officials perceive as problematic. Scholars frequently understand neighborhood problems in terms of a lack - of houses, resources, jobs, social order. I instead develop a relational analysis of a context of poverty (Desmond 2015). Following American legal realists (Hale 1923; Cohen 1927), I take property as a social relation, asking how and why organizers remake property 
institutions in order to address disuse and disempowerment. What emerges is a relational account of an effort to rework neighborhood institutions (Allard and Small 2013).

This approach contrasts with prior studies of neighborhood effects. First, neither Englewood or Chicago is taken as typical of other neighborhoods or other cities (cf. Small 2007). Instead Englewood provides an "extreme" case (Flyvberg 2006), exposing connections between property institutions, attitudes toward law, and collective efficacy. Second, I follow Bell (2016) in studying actors' attitudes and strategies concerning neighborhood institutions through interviews and participant observation, instead of quantitative analyses of neighborhood surveys.

I conducted an ethnographic study of Chicago's emerging urban agriculture sector between 2011 and 2015. This involved attending (and, later, organizing and facilitating) meetings on food and land use policy; observing community discussions on land tenure and land trusts; volunteering at community gardens and urban farms; and researching and co-authoring a report recommending institutions for expanding agriculture on Chicago's far South Side (Co-author and Author 2015). This participatory research was a "situated intervention," not simply disinterested observation (Mosse 2006, 952). Instead of aiming to avoid "changing the system," the collaboration with community organizations through research on a community problem has sought to inform urban policymaking (Stoecker 1991, 107).

Based on participant observation, I identified and interviewed 43 respondents involved in developing urban agriculture land use policy and practices. These included farmers, garden organizers, public officials, foundation staffers, policy advocates, community organizers, and attorneys (Table 1). Semi-structured interviews based on individualized protocols solicited respondents' views on the emerging institutions that make land available for farms and gardens.

This article focuses on Englewood's urban agriculture district - consistently identified as a critical site for experiments with ways to effectively and equitably manage the use of urban farmland - and on growing on the South Side in general. It attends in particular to the visions and projects of African-American respondents most directly involved in developing plans for the district, and in setting up farms in Englewood and other South Side neighborhoods. These eight respondents, however, represent a minority of the total sample. To explain how understandings of the purpose of local property institutions - community empowerment versus economic productivity - vary along racial lines, the article also draws on data from interviews with some of the 35 white respondents. 
Table 1. Interviewee Distribution by Organization and Race (B=Black | W=White)

\begin{tabular}{|c|c|c|c|c|c|}
\hline Urban Farms & & $\begin{array}{l}\text { Community } \\
\text { Gardens }\end{array}$ & & $\begin{array}{l}\text { Land Trusts and Urban } \\
\text { Ag. Policy Organizations }\end{array}$ & \\
\hline $\begin{array}{l}\text { Chicago Botanical } \\
\text { Garden }\end{array}$ & $2 \mathrm{~W}$ & 61st Street Garden & $1 \mathrm{~W}$ & $\begin{array}{l}\text { Advocates for Urban } \\
\text { Agriculture }\end{array}$ & $2 \mathrm{~W}$ \\
\hline City Lights Farm & $\begin{array}{r}1 \mathrm{~B} \\
1 \mathrm{~W}\end{array}$ & Blacks in Green & $1 \mathrm{~B}$ & $\begin{array}{l}\text { Chicago Food Policy } \\
\text { Advisory Council }\end{array}$ & $\begin{array}{r}1 \mathrm{~B} \\
1 \mathrm{~W}\end{array}$ \\
\hline Eat to Live Farm & $\begin{array}{r}1 \mathrm{~B} \\
1 \mathrm{~W}\end{array}$ & Kumunda Garden & $1 \mathrm{~W}$ & Grow Greater Englewood & $2 \mathrm{~B}$ \\
\hline Growing Home & $\begin{array}{r}1 \mathrm{~B} \\
2 \mathrm{~W}\end{array}$ & $\begin{array}{l}\text { McKinley Park } \\
\text { Community Garden }\end{array}$ & $1 \mathrm{~W}$ & NeighborSpace & $3 \mathrm{~W}$ \\
\hline Growing Power & $\begin{array}{r}2 \mathrm{~B} \\
1 \mathrm{~W}\end{array}$ & $\begin{array}{l}\text { Peterson Garden } \\
\text { Project }\end{array}$ & $1 \mathrm{~W}$ & Openlands & $4 \mathrm{~W}$ \\
\hline $\begin{array}{l}\text { Perry Avenue } \\
\text { Farm } \\
\text { Urban Canopy }\end{array}$ & $\begin{array}{l}1 \mathrm{~B} \\
1 \mathrm{~W} \\
3 \mathrm{~W}\end{array}$ & & & & \\
\hline Total & $\begin{array}{r}6 \mathrm{~B} \\
11 \mathrm{~W}\end{array}$ & Total & $\begin{array}{r}1 \mathrm{~B} \\
4 \mathrm{~W}\end{array}$ & Total & $\begin{array}{r}3 \mathrm{~B} \\
10 \mathrm{~W}\end{array}$ \\
\hline Public agencies & & Funders & & Other & \\
\hline $\begin{array}{l}\text { Chicago } \\
\text { Department of } \\
\text { Planning and } \\
\text { Development }\end{array}$ & $2 \mathrm{~W}$ & $\begin{array}{l}\text { Anonymous } \\
\text { foundation }\end{array}$ & $1 \mathrm{~W}$ & Land trust experts & $2 \mathrm{~W}$ \\
\hline $\begin{array}{l}\text { Chicago Park } \\
\text { District }\end{array}$ & $\begin{array}{r}1 \mathrm{~B} \\
2 \mathrm{~W}\end{array}$ & $\begin{array}{l}\text { Chicago } \\
\text { Community Loan } \\
\text { Fund }\end{array}$ & $1 \mathrm{~W}$ & $\begin{array}{l}\text { Urban agriculture } \\
\text { attorneys }\end{array}$ & $3 \mathrm{~W}$ \\
\hline Mayor's Office & $1 \mathrm{~B}$ & $\begin{array}{l}\text { Fresh Taste Funder } \\
\text { Collaborative }\end{array}$ & $2 \mathrm{~W}$ & & \\
\hline \multirow[t]{2}{*}{$\begin{array}{l}\text { Metropolitan } \\
\text { Water } \\
\text { Reclamation } \\
\text { District }\end{array}$} & $3 \mathrm{~W}$ & Heifer International & $1 \mathrm{~W}$ & & \\
\hline & & $\begin{array}{l}\text { IL Department of } \\
\text { Natural Resources } \\
\text { Kinship Foundation }\end{array}$ & $\begin{array}{l}1 \mathrm{~W} \\
1 \mathrm{~W}\end{array}$ & & \\
\hline Total & $\begin{array}{r}2 \mathrm{~B} \\
7 \mathrm{~W}\end{array}$ & Total & $7 \mathrm{~W}$ & Total & $5 \mathrm{~W}$ \\
\hline
\end{tabular}

Note: Total discrete individuals interviewed: 43 (8B | 35W). Because some individuals have worked with multiple organizations, columns do not tally. 


\section{BACK TO THE LAND ON CHICAGO'S SOUTH SIDE}

Under the administration of Mayor Rahm Emanuel, city officials sought to scale up urban agriculture. "We're talking about neighborhoods where some of the unemployment rates are really high," Mike Simmons, Emanuel's first policy director, told me. "People don't have access to grocery [stores], and there's a ton of vacant land." Farms seemed full of promise. "The job potential," Simmons explained, "is enormous. If you look at the amount of vacant land that's out there... let's just put it this way: the opportunity to grow fruits and vegetables is limitless."

This sense of limitless potential informed the plan, approved in 2015 by Chicago's city council, which named Englewood, a low-income, predominantly African-American neighborhood on the South Side as the site of Chicago's first urban agriculture district. The vision for such a district was not new. A decade earlier, Englewood residents who took part in a neighborhood planning process identified agriculture as a potential source of fresh food, job training, and employment (Teamwork Englewood \& LISC 2005). City officials responded by selling a piece of vacant land in Englewood to a group of advocates for the homeless, who had been looking to start a farm that would provide job training (Author 2017). This became Growing Home, Englewood's first farm. The site raised permitting issues, which contributed to a push to allow commercial farming, and a 2011 amendment to the zoning code.

Growing Home soon looked to expand. The city transferred a second parcel to NeighborSpace, a land trust that the city, park district, and Cook county had created in 1996 to preserve community gardens. Formally an independent nonprofit organization, NeighborSpace relies heavily on public funding and reserves a majority of its board seats for public appointees. In discussing the expansion of Growing Home, these board members decided that NeighborSpace could support farms as well as gardens (Author and Co-author 2017). This shift informed the city's plan for Englewood's new agriculture district. The plan envisions land held in trust for both nonprofit farms and for entrepreneurial for-profit growers earning what city and foundation officials frequently call "supplemental income."3

In the months after Englewood was named the city's first urban agriculture district, urban farmers, community organizers, and urban planners met for lunch and conversations at Kusanya, a neighborhood café. It remained uncertain what the institutions of the new district would look like. Would NeighborSpace expand, to own and manage the land? Who would own the farms, and work the land? The people gathering at Kusanya aimed to answer these questions, and design institutions for the new district.

One July afternoon, I met up with Sonya Harper. After growing up in Englewood, Harper left to work in local television news. Later, she moved back to the neighborhood to work on community outreach for Growing Home. She then co- 
founded Grow Greater Englewood, a group that helped convene the conversations at Kusanya. "What do you think," she asked me, "black people in Englewood, you think they want some white person coming and telling them what to do? Owning the land and telling them to work on it?" Clearly, the answer was no.

"Sounds like slavery to me," Harper continued. "Now, maybe if we did not have a history of slavery in this country, then we wouldn't feel that way. But since we have, yeah - no, you cannot own the land that we're going to farm on. Sorry. Nope. Not going to happen. If that's the case, we'll concrete the land out, and put parks on it... If it's got to be that way, we're not going to be a part of it." "Harper's frank assessment highlights the tensions inherent in using agriculture as a basis for community development in African-American neighborhoods - and the stakes of how local property institutions are designed.

\section{THE AMBIVALENCE OF URBAN FARMING}

For some African-American residents and growers on the South Side, the prospect of going back to the land provokes mixed memories. It recalls visions of self-sufficiency and sovereignty, rooted in forebears' practice of growing their own food. It also recalls the exploitation of slaves and sharecroppers. The emerging institutional visions for farms on Chicago's South Side are informed by these ambivalent memories.

A mile east of Englewood, Naomi Davis runs Black in Green, a nonprofit that builds gardens and promotes neighborhood sustainability in the West Woodlawn neighborhood. Her grandmother's farm in Kentucky provides inspiration. "Everything they ate, they grew," Davis recalls. "They thought they were poor, but they were rich: they were a self-sustaining unit." 5 Grounded in "grannynomics," Davis' project aims to create a self-sustaining urban village. "We really need to be advocates for our sovereignty," she explains, even though this "sometimes feels like a strange word to use in the context of just a neighborhood." But the strength of Chicago's Polish and Chinese neighborhoods, as Davis sees it, is based on sovereignty. "They have a sovereign state of mind," she observes, "that feels natural in the declaration of their right to resolve transactional issues in their self-interest."

Erika Allen also links farming and sovereignty. A sharecropper's granddaughter, Allen runs Growing Power, one of Chicago's most prominent farms; she also chairs the Chicago Food Policy Advisory Council and is a park district commissioner. The inspiration for her urban farming, Allen explains, is the belief that "People need to control their food system, to have food and land sovereignty." (Jefferson 2009) In 2015, Allen and I convened a community meeting on Chicago's far south side to discuss the possibility of expanding urban farming. If farmers 
"have no land access or sovereignty," Allen warned in opening the meeting, "then we have no food security." 6 Farming promises food security, and the basis for asserting community sovereignty.

Yet urban farming also digs up uncomfortable memories. Anton Seals, a South Side community organizer, has helped develop Eat to Live Farm, and cofounded Grow Greater Englewood along with Harper. "If you see some white people showing up farming," he told me, "they're like, "Come learn about this shit." He continued: "in a lot of folks' mind, particularly African Americans, we're looking like, 'Who the fuck is you?!' There's a level of resistance... [that] has to totally do with the history that's unresolved." For older residents, the tension is clear. "The elders would say they wouldn't touch a tomato," Seals said. "They wouldn't go back to do any of that work... even though they lived an agrarian lifestyle — and at that point they're not slaves, they're sharecroppers - the work is very hard."

Young people are also resistant. "You won't find many people like, 'Yeah, I want to till land," Seals told me. "You ain't going to find no young punk[They'll say,] 'What? Till? Motherfucker, I'm not touching no damn-nothing."' Despite the obvious tension, most people in the urban agriculture community, Seals notes, "don't really talk about race-and, in particular, race as it's connected to land-[which] was, for many black people, why they moved to the fucking north to begin with."7

Davis, for her part, does note the connection. "There's so much shame associated with caring for the land right now," she lamented to me. "It's like, 'I ain't doing that slavery stuff." "This affects her work with young people, who can earn a summer stipend while helping her organization. "They were laaaaazy," she remembered of one group, "but, God bless them, to their credit, they carried a ton of limestone around." Starting to laugh, Davis admitted, "it was like slavery, in that hot sun. I did feel kind of bad." Yet in the end, she notes, "they were getting paidand I wasn't." Similarly, a white supervisor at the Growing Home farm told me that nearly every season, usually on a hot day, a trainee will compare the work to slavery. She then has to explain why it is different: Trainees are paid. They can leave. And they are building skills that many of the farm's white visitors would pay dearly to learn. ${ }^{8}$

Farming on the South Side entails forging hope out of a painful history. "We're taking this really broken system of agriculture that exploited labor first through slavery and then through sharecropping," Allen explains, "and reclaiming that and using it to create sustainable communities." Urban farming, she concludes, offers "a recovery from the historic impact of structural racism that manifested through the agriculture system." (Chu 2018)

Uncomfortable memories of plantations and sharecropping demand new visions. The plantation, Katherine McKittrick $(2013,5)$ has argued, offers a basis 
for "discussion of black life within the context of contemporary global cities and futures." Such a discussion is underway in Englewood. By inspiring visions of sovereignty along with memories of exploitation, the move to expand urban farming has exposed fertile ground for reimagining who can own, control, and benefit from a neighborhood's land.

\section{CULTIVATING LEGAL OPTIMISM}

Englewood's African American residents and organizers have reason to be cynical about the notion that the institutions of property could help solve problems. Even having left slavery and sharecropping behind, African Americans who moved to northern cities faced rules that limited their ability to own and use urban property - from redlining and contract sales to the foreclosure and eviction crises (Coates 2014; Desmond 2016; Rothstein 2017). Despite public commitments gained through the civil rights movement to ensure equal access to education, jobs, housing, and other resources, Chicago remains deeply segregated and unequal.

The discussions at Kusanya café, nevertheless, reflected a remarkable degree of optimism about the possibilities of property. They produced a prospectus for a business to be called Englewood Community Farms. This proposed that a new neighborhood-based community land trust cooperative receive land from the city, to hold and manage for "community-controlled farms." (Urban Farm Pathways Project 2015) Organizers soon founded the Ujamaa Community Land Trust, to promote ownership and control over local resources by Englewood residents.

Organizers' turn to the community land trust model picks up on a recent trend, and taps into a deeper history. Since the 1970s, the community land trust (CLT) has become a well-established model for affordable housing. ${ }^{9}$ Recently, people have begun to adapt the model for urban agriculture, in hopes that it could also help growers enjoy affordable and secure land tenure (Rosenberg and Yuen 2012). It also incorporates community input in land use decision making more than is typically the case with space land trusts like NeighborSpace.

Organizers appreciated that the CLT model has roots in African-American struggles for self-determination. "We were considering the land trust from a historical perspective," Harper explained to me, "because, right after slavery, that's what black folks - co-ops and land trusts is what kept them alive." Indeed, as Nembhard (2014) documents, economic cooperation has played a crucial part in African Americans' efforts to survive in the face of racism. Many cooperatives involved black farmers, as Du Bois $(1907,42)$ observed in projects developed by the Freedmen's Bureau. During the civil rights era, agricultural cooperatives again supported struggles for power and freedom in the South (White 2017). 
The community land trust initially emerged as a legal form devised to protect land for African-American farmers in Georgia (Gray 2008, 70). During the 1960s, Slater King, the cousin of Martin Luther King, Jr., joined with Robert Swann to create New Communities, Inc. The project bought over 5,700 acres of land, which were used by African-American farmers. After the New Communities project foundered, CLTs became known primarily as a vehicle for affordable housing. In founding a CLT to hold and manage farmland, organizers are returning to the roots of this model of collective land tenure.

Through its name, the Ujamaa Community Land Trust declares its commitment to black cultural and economic empowerment. Ujamaa, the land trust's vision statement notes, is one of the principles of the Kwanzaa celebration; it is a Swahili term meaning "cooperative economics" or "family hood."10 The creator of Kwanzaa described ujamaa as an effort "to build and maintain our own stores, shops and other businesses and to profit from them together" (Karenga 2008).

By developing a community land trust in a predominantly black neighborhood, Ujamaa's founders have raised a question: Who is part of the community? In 2015, organizers were still thinking this through. "All we know," Harper told me, "is that community's going to run it. And community means people who live here." Founded as a "membership-based organization" and a "communitybased cooperative," Ujamaa promises to let "residents and facilitators make decisions for the organization." 11 Compared to NeighborSpace, a citywide organization whose board of directors is primarily composed of government appointees, Ujamaa has more flexibility in shaping how it is governed, who can become a member, and what role members play.

The flexibility of "community" could permit Ujamaa's leaders to be both inclusive and exclusive. "The community," Levine $(2017,1159)$ has observed, is a "floating signifier" - a concept that is "valued yet vague," since it is "overloaded with meanings and no single agreed-upon definition." Harper's statement that community means "people who live here" offers one possible meaning. But she also alludes to other possible meanings: people who live in "Greater Englewood," or the South Side, or who simply look in some way like Englewood's residents. The boundaries of community - and the constituency of a community land trust - are malleable. "Community" can be expanded to permit inclusion, or narrowed to justify exclusion. ${ }^{12}$

Ujamaa could play a role in determining who may set up farms in Englewood's urban agriculture district. Harper expressed reluctance to accept white farmers coming from other neighborhoods. This was "not about keeping people out as much as it's about empowering the people that live here," she explained.

The farmers, yes, it's more important that they are black. Yes, we want them to be from Englewood, but it's more important that 
they're black, who aren't — not even black, but they look like the people who live around their farms. Because even that's changing.

With Latino residents moving into Englewood, Harper recognizes the difficulty of organizing along purely racial lines. "[I] Can't even say black, but they [should] look like the people that live there," she suggested. "And I almost want to go put a percentage on it, but I think you can't do that." Harper's hesitation suggests an awareness of the legal limits to private organizations relying on racial categories in defining their membership, or serving the public. But the vision is of a private organization that will help decide who gets access to land.

It is difficult to neatly classify the approach to land ownership and use being forged by Ujamaa as either conservative or progressive. The community land trust promotes ownership. But it does not do so in a way that fits with the conservative "ownership society" ideal-in which individually-owned private property fosters a responsible citizenry, while spurring market exchange and economic growth (Boaz 2004; de Soto 2000). Ownership is instead envisioned as collective, and a way to protect a community from market forces - such as outsiders eager to lease or buy cheap land-rather than to unleash them.

The project also breaks from the typical progressive approach to property. To be sure, its aim to increase deliberation and participation by splitting and reallocating the "bundle of sticks" that constitute property rights would be familiar to progressives (Singer 2014). But participation is not Ujamaa's only aim; deliberation alone, after all, can fail to account for pre-existing inequities of power and wealth (di Robilant 2014, 414-415). The organization also aims to privilege local residents, by excluding people who are not considered part of the community. This departs from progressive approaches to property, which generally aim to destabilize the notion that the right to exclude is central to property (Alexander et al. 2009; cf. Smith 2012).

Ujamaa appears to be moving toward a progressive vision of property that champions the right to exclude, in order to address the distributive consequences of a "history of race-related acquisition and distribution of property [that] cannot be simply written off" (Rosser 2013, 109). This more radical, racial approach to reworking the institutions of property privileges black control over land, in order to redress and make reparations for property rules that have historically privileged whites (Harris 1993; Coates 2014). As we will see next, organizers hope that this reworking of property relations will not only redistribute control over material resources, but also reshape how residents think about their community. 


\section{COLLECTIVE EFFICACY THROUGH COMMUNITY OWNERSHIP}

"If someone breaks ground on a football field, two football fields, and they're growing, who owns that?" Seals asked me. "Who gets to benefit from it?" For organizers like Seals and Harper, these are essential questions. City officials, Seals felt, wouldn't necessarily ask them:

The city's probably going to go to people where it's the easiest to do

it - who have access to money, who are organized in a way that seems efficient to them. But does it then resolve the problem that the community that you're in is looking to resolve?

If the problem were simply creating access to food and job training, the city's approach would be fine. But Seals and Harper saw greater possibilities: the urban agriculture district could spur new institutions that make residents feel empowered to solve community problems.

Englewood's residents, Harper observed, often lack faith that projects will benefit them. "I've got a whole lot of convincing on this end," she told me. Residents have "this perception and brainwashing of 'We can't do it, we ain't going to get it, it ain't going happen, it's just another dream that somebody's selling us." This mindset can keep residents from acting in their own interest: "We can't even take the good stuff for us, because we've been trained not to."

Harper pushes back. When residents see a new project, she explained, many will say, "That's going be for somebody else. That's going be for the white people when they come." She replies, “'No, dummy, it's for you. Stand up, and let's help to build it out. Come on!'” But the mindset has deep roots. "How beat down can we be?" she asked. "That's just how we are... passed down from generations, trained to think."

Urban farming, together with community ownership, could convince people to become engaged. "This community looks like it is because we think a certain way about it," Harper explained. But, she added,

Having community have ownership, control, and then actually be the beneficiaries and the workers, and the producers on that landthe vision and picture of that is just so empowering, that it would definitely start chipping away at some of that brainwashing that teaches us the opposite.

What Harper hopes to see produced, more than vegetables or jobs, is trust among residents that they can take control of their community, and, working together, address its problems.

The prospect of community empowerment helps explain the optimism associated with the particular institutional form of the CLT. This new neighborhood property institution could help growers set up new farms, yielding crops, job training, and jobs. But if those were the only goal, Ujamaa would not be necessary. 
NeighborSpace, an established organization, already has access to public funds and public land; it could hold land for farmers just as easily as a new organization. Ujamaa, however, promises to reallocate legal powers over the neighborhood's resources. Doing this, Harper expects, would show that residents can collectively own and manage community resources. Relying on NeighborSpace, by contrast, would not. Harper's goal is to undo the "negative brainwashing that we have about ourselves." This, she concluded, "is the most important thing-because it really, really keeps us down, up in this community."

It is crucial, then, that Ujamaa be a black-led organization. To convince Englewood's African-American residents that they can collectively solve problems requires demonstrating that people like them can take ownership and control. Yet as a social relation, ownership is difficult to observe. Ujamaa gives that relation a face: one that is proudly African American, and honors a tradition of black economic cooperation.

Presenting Ujamaa as a black organization is strategic. "You don't usually say, 'white-led organizations." Seals pointed out to me. "It's 'an organization.' It's an assumption. When you say, 'black-led,' it means it's something else. Even in our dialogue, these are these assumptions that we're all used to." Ujamaa, Seals added, "doesn't have to be all-black." It can involve and work with people from other racial backgrounds. But through its name and its leadership, it makes clear that African Americans are taking ownership, control, and power. Being black-led, Seals emphasized, is "part of what we need to demonstrate."

Organizers in Englewood are running a property experiment. The proposition being tested extends the links urban sociologists have made between a sense of individual ownership and collective efficacy (Sampson 2012; Walton 2016). Here, the hypothesis is that collective efficacy can increase not only when residents develop a sense of individual ownership, but also when a local institution demonstrates collective ownership of neighborhood resources.

The project to demonstrate collective, African-American ownership points to a new tie between race and collective efficacy. Contexts of concentrated disadvantage - defined in part by high rates of African-American residents - tend to have lower rates of collective efficacy (Sampson 2012, 199). This, of course, does not mean a neighborhood's racial composition causes its level of collective efficacy. Rather, as Sampson et al. (1997, 919) conjectured in proposing the concept of collective efficacy, if racial and economic exclusion can disempower individuals, so could "the alienation, exploitation, and dependency wrought by resource deprivation act as a centrifugal force that stymies collective efficacy." In Englewood, organizers believe that ownership and control of resources by AfricanAmericans could undo alienation, and foster the type of community-level trust that sociologists call collective efficacy. 
This strategy echoes earlier theories that linked property and black empowerment. Decades before urban sociologists developed theories of neighborhood effects, Black Power scholars and activists argued that empowerment required Black ownership. In "Behind the Black Power Slogan," Harold Cruse ([1968] 2009, 238-39) observed that the African-American "does not own anything-even what is ownable in his own community." He concluded that "to fight for black liberation is to fight for his right to own." When it came to land, Stokely Carmichael agreed. "We already own it; we paid for it with 400 years of our sweat, our blood, and our suffering," he declared. "Until we take the land we are gonna stay poor." (Cleaver 1968, 52)

Robert Blauner, in observing Black Power strategies, agreed that projects to develop ownership can shift a community's collective mindset. Following Fanon ([1961] 2004), Blauner $(1972,90)$ noted "a general dispiritment that accompanies social oppression." He departed from Fanon in rejecting the notion that violence could cast off this dispiritment (Id. 91). Instead, he concluded that projects to cultivate cultural nationalism and to assert ownership and control over community resources were more likely routes to empowerment (Id. 91-96).

In its effort to change how residents think by rendering collective AfricanAmerican ownership both possible and visible, the Ujamaa CLT revives a longstanding strategy. As a strategy for fostering collective efficacy, building a sense of community ownership could seem commonsensical. Why, after all, would residents of a race-class subjugated community join together to fix local problems, if they had no faith that neighborhood institutions would keep the fruits of their labor local? A local institution that ensures community ownership solves that collective action problem.

Ujamaa, however, also reflects a more radical proposition. It points to possible shortcomings of conventional approaches to fostering collective efficacy, such as investing more resources in a disadvantaged neighborhood, or "increase[ing] organizational opportunities for citizen participation in decision making." (Sampson 2012, 422) It is indisputable that a neighborhood like Englewood could benefit from more resources, and that its residents should have more opportunities to participate in decision making. The promoters of Ujamaa go a step further, proposing that the way to build collective efficacy in a predominantly African-American neighborhood is not to simply permit more say in decisionmaking in how a white-led organization allocates resources, but instead to create a black-led organization that gives residents the power to own, control, and benefit from those resources. 


\section{A CROWDED FIELD OF VISIONS}

The strategies that South Side organizers are developing represent one vision among many that have sprung up to imagine how to organize and expand the field of urban agriculture in Chicago. Stepping back to view the city as a whole, one sees that the vision described in the previous sections represents a minority view - one both made possible by and tailored to the reality of a majority-minority neighborhood. The Ujamaa CLT is imaginable both due to the vacant lots left by Englewood's history of disinvestment, and the tradition of black empowerment and resistance that has informed organizers' strategies.

One hears different visions from the people - often white people-who make decisions about urban agriculture and land use policy elsewhere in Chicago. Not surprisingly, the priorities described by white city managers, land trust leaders, and urban farmers who I interviewed did not turn on black ownership or empowerment. Instead, they focused on increasing productivity, creating jobs, or permanently protecting community gardens.

Visions of what urban farmland will produce vary. Some see farms yielding more than just food. "We're running an experiment," Rebekah Silverman, the associate director of Growing Home, explained to me, "testing the hypothesis that building urban farms will increase human capital and the financial health of Englewood."'13 A former director of NeighborSpace, Mary Jo Schnell, recounted how, to cultivate support among elected officials explained, she would explaine that gardens produce "community betterment" and "social capital." 14

Typically, however, visions of productivity focus on food or jobs. To be sure, these are not only visions of white people. Mike Simmons, the former policy director to Rahm Emanuel who touted the "limitless" potential of urban agriculture to produce jobs and food, is African-American. But when white growers seek to realize these visions by using land in black neighborhoods, it can create tensions. Ken Dunn, a white grower with decades of experience, has long dreamt of converting Chicago's thousands of vacant lots into farms. In practice, he has farmed a few parcels that the city has offered on a short-term basis. In 2014, he partnered with Brandon Johnson, a black community developer, to start a farm in a South Side neighborhood a mile east of Englewood. They received a lease of land from the Department of Planning and Development (DPD), but as Dunn was building the farm, the local alderman decided against renewing the lease. Dunn stated the problem bluntly: it was "the black issue: the alderman wanted Afro-Americans farming it." 15 Johnson was more diplomatic. "It rubbed some of the leadership in the community the wrong way," he explained. "Here was a white guy doing something that a black man could be doing." 16 Johnson saw the situation as more complex. "The realities of that labor pool were not like that," he told me. "Only a 
handful of people, black, white, and other, can do this in this city." (The grower who took over the lease is black, but, like Dunn, is not from Washington Park.)

Officials in City Hall are aware of these constraints. When I spoke with Kathleen Dickhut, a deputy commissioner in DPD, I noted that some people dreamed of farms in every vacant lot. She interrupted. "Who would that be," she asked incredulously, "that's planting all that land in all those neighborhoods?" She pointed out that the city does not hold thousands of contiguous lots, and stressed that "there's no cadre of people that are going to farm all this vacant land. Who's paying those people?" For Dickhut, these questions force a reality check for the most ambitious visions of productivity.

In Englewood, Harper recognized the challenge. Would there be African Americans ready to set up commercial farms in the neighborhood? Some, she noted, had been developing growing skills at a black-run farmer training center south of Chicago. Eventually, they could set up farms in the urban agriculture district. This would be harder than simply inviting in white growers like Dunn. But Harper was committed having Englewood's farmers look like its residents.

For conservationists, the priority is permanently protecting land for community use in general, rather than ensuring ownership or control by a particular group. Ben Helphand, the current director of NeighborSpace, has seized opportunities to build the land trust's inventory. "Historically, savvy and successful community garden groups ride the coattails of whatever kind of crisis or trend is hot and fundable," he explained at a meeting of open space advocates. "I've been riding the wave of interest in urban ag, trying to get as much land in Chicago as possible." ${ }^{17}$ Helphand aims to preserve land for community use, out of the market, even if someday it is used for something other than farms. Mary Jo Schnell, the former NeighborSpace director, had a similar instinct. "Given how everybody looks at land still," she told me, "I don't think land should be private." ${ }^{18}$ Moving cityowned land into NeighborSpace's inventory offers a pragmatic way to achieve this goal, even if it does not advance black organizers' visions of cultivating a sense of empowerment by asserting local control over community resources.

In one instance, a white grower was skeptical about the prospects for a community land trust in Englewood. A year before the conversations at Kusanya Café, I spoke with Harry Rhodes, who as director of Growing Home had set up the neighborhood's first commercial farm. Rhodes, who is not from Englewood, expressed doubt. "I don't think it would be real helpful to the community, because the community is so disparate," he told me. "You have a lot of different people saying they represent the community, and then you have the community fighting." Englewood, he noted, has three different pastors, who don't always pull together. "It's important to have an organization like Grow Greater Englewood, which can try to bring everybody together," he said. "But I don't think a community land trust, per se, would be all that helpful."19 If "community" is a floating signifier (Levine 
2017), Rhodes worried a community land trust would only fuel struggles over who is in and who is out.

The vision of using a black-run community land trust to build a sense of community empowerment faces hurdles. The primary challenge is not the sort of doubts voiced by Rhodes. Most white respondents did not voice such skepticism. Rather, it is that when white growers and policymakers envision the field of urban agriculture in Chicago, they imagine something else: producing food or jobs, opportunities for land conservation. Race is not entirely absent from these visions. Black neighborhoods like Englewood are understood as most needing jobs and fresh food, and most abundant in vacant land. But the vision of making black community empowerment central to the institutions being created to scale up urban farming is not the dominant view. To gain traction in a field dominated by other visions, black organizers will have to demonstrate why Ujamaa complements those visions - or perhaps, is a prerequisite to realizing them. After all, as Harper noted, outsiders can forget about visions of an urban agriculture district in Englewood if it doesn't involve community land ownership: "If it's got to be that way, we're not going to be a part of it." 20

\section{DISCUSSION: THE POSSIBILITIES OF PROPERTY}

The experiences of organizers in building the institutions of Englewood's urban agriculture district help explain why property has inspired promise in a neighborhood where urban sociologists would typically expect residents to be cynical about calling on law and legal actors. More broadly, they suggest why people would perceive more promise in the institutions of private law than those of criminal law. And they point to potential limits to this legal optimism. I discuss each of these points in turn, while acknowledging limitations of this study and indicating directions for future research.

Property's promise. Property is unique among other forms of law: it invests owners with a sense of sovereignty. The legal realist Morris Cohen (1927, 8-9) traced this to a distinction in Roman law between "dominium, the rule over things by the individual, and imperium, the rule over all individuals by the prince." Private property, Cohen explained, empowers owners to dictate relations with nonowners, while constraining the state's power to intervene. In race-class subjugated communities like Englewood, residents live in landscapes scarred by decades of discriminatory policy, and recall ancestors treated as property. For organizers interested in self-determination, one can see why asserting dominium over land would be enticing. While criminal law typically poses a relation between the state and individuals, the turn to property allows organizers to create institutions of collective ownership, and to assert community sovereignty. 
The creative potential of property also springs from a persistent opposition in how it is imagined. The traditional view of property, defined centrally by the right to exclude, remains the lodestar of conservative scholars (e.g. Smith 2012). Meanwhile, the image of property as a bundle of rights and duties, which may be split and re-bundled to serve social purposes, still guides progressive thinking (Singer 2014). These understandings persist and coexist in legal consciousness, and appear simultaneously in the form of local institutions that aim to solve social problems by empowering community residents to exclude outsiders. The Ujaama CLT offers one such example, adjusting the rights and duties of ownership to ensure residents make decisions and enjoy benefits, while reserving their collective right to exclude outsiders.

Property's promise also flows from its affective power. Property institutions permit claims that residents have rights to use and benefit from land, while others do not. Asserting such formal claims, organizers hope, will also generate feelingsof trust, of power, and of possibility. (Of course, as both organizers and observers recognize, the boundaries of who is inside and outside a community are difficult to define, and could also spur feelings of distrust, and conflict.) By demonstrating African-American ownership, organizers hope Ujaama will cultivate a collective affect - one that activists fifty years ago would have called Black Power. If the end goal is solving community problems, the proposition is that a new property institution will permit community ownership of a key neighborhood resource, and thereby inspire residents to feel that solutions to local problems are achievable and worth working toward.

The pathway organizers in Englewood have identified between property and collective efficacy offers a new perspective on the role of institutions in determining neighborhood conditions (Allard and Small 2013). It calls for not simply tallying a neighborhood's schools or community organizations, but for examining both who owns and controls those institutions, and how effectively they cultivate a sense of community ownership. The community land trust offers a clear but relatively rare example of such an institution. Limited equity housing cooperatives, condominium associations, and homeowners associations could provide fruitful terrain for future research into neighborhood property institutions and collective efficacy.

Private legal ordering. Property institutions also inspire legal optimism because they allow non-state actors to become legal agents, and engage in private ordering by acting with the law (Ewick and Silbey 1998). Instead of calling on state actors to solve local problems, organizers and residents can adapt a range of available ownership forms (di Robilant 2014). Despite its undeniable "history of race-related acquisition and distribution" (Rosser 2013, 109), property law offers institutional forms that can empower residents of subjugated communities. 
Other forms of private law could plausibly inspire a similar sense of promise. Contract law also empowers people to act directly as legal actors. The more optimistic assessments of micro-credit schemes have found that contractual obligations can build community capabilities and foster collective action (Anthony 1997; Sanyal 2014). Such accounts resonate with the notion that contracts not only formalize legal relationships and build economic capacity, but also cultivate noncontractual relations of solidarity (Durkheim [1893] 2013).

Community struggles against unjust contracts offer a more complex picture of cynicism and optimism vis-à-vis private law. The campaign against racially discriminatory and exploitative contract sales of homes to African Americans in Chicago offers an example. Satter $(2009,271)$ relates the cynicism of one community organizer: "We are losing faith in those who say that justice can be achieved within the framework of the law." Yet the campaign also organized residents in their role as parties to contracts, appealing to both law and morality as they used payment strikes, eviction blockades, and lawsuits to force renegotiations and challenge discrimination. The resurgence of contract sales (Burns 2017) and the eviction and foreclosure crises call for a better understanding of how and when private law can inspire legal optimism, and help residents feel empowered to address neighborhood problems.

Limitations. The experience of organizers developing institutions for Englewood's urban agriculture district reveals links between property, legal optimism, and collective efficacy. It does not mean that these links are urban universals, which apply to all cities and communities. The case study exposes mechanisms that merit exploration and elaboration in other settings. The findings here call for further study of how neighborhood property institutions can inspire legal optimism and cultivate collective efficacy. More broadly, they suggest how scholars could develop a richer understanding of legal cynicism by looking beyond criminal law.

Finally, the experience of Englewood points to how the legal optimism inspired by property could itself be limited. Private law lets people act directly as legal agents, but private ordering must ultimately be endorsed by the state. Ownership can inspire a sense of sovereignty, but it does not confer sovereignty as such. Should state actors refuse to endorse a community's effort to create new neighborhood property institutions, a project that had fostered legal optimism could instead become a new basis for cynicism.

This highlights the contingency of the institutional project underway in Englewood. The success of the Ujamaa CLT turns on organizers demonstrating to residents that they can take control of community resources. As Harper notes, it would be legally problematic to limit use of farmland exclusively to African Americans. As a private organization seeking support from the state, the land trust would have to act in a way that is color-blind. Ujamaa's organizers will have to 
convince city officials that their new land trust can be trusted to receive and responsibly manage city-owned land. Should they fail to do so, Ujamaa could linger as a land trust that lacks any land to hold in trust. Although it would formally remain an institution of collective ownership, without any resources to actually own and manage, the land trust would likely struggle to demonstrate community ownership and control, or cultivate a sense of empowerment.

The institutions of property can inspire promise-but promise can be fleeting. The legal optimism generated by new property institutions could prove akin to what Lauren Berlant $(2011,1)$ has termed "cruel optimism"-a relation that "exists when something you desire is actually an obstacle to your flourishing." The "good life" to which people aspire, Berlant argues, is unattainable under contemporary capitalism. Similarly, given the realities of urban politics, the promise of sovereignty and community self-determination offered by new property institutions could also be unattainable. Property offers the promise of private ordering, local control, and limits to interference by a discriminatory state. But projects to develop new property institutions ultimately require the assent of state officials, and can thus be frustrated. The turn to property is not a panacea for the problems faced by organizers and residents in disadvantaged neighborhoods. But for organizers working to help residents solve community problems - and for scholars interested in that process-local property institutions hold promise. 


\section{NOTES}

${ }^{1}$ Strategies linking Black ownership and empowerment have been interpreted as resisting internal colonialism. Blauner (1972, 83-106), for example, followed Black Power scholars and activists (e.g. Cruse [1968] 2009; Cleaver 1968) in viewing ownership as a nonviolent way to undo the alienation felt by colonial subjects (Fanon [1961] 2004). Blauner (2001) and others (Burawoy 1974; Omi and Winant 2015, 91-93) later critiqued and dismissed internal colonialism, but scholars comparing gentrification to settler colonialism have revived the theory (e.g. Safransky 2014). Tracing links between ownership and empowerment, however, does not require adopting — or disavowing - a colonial perspective on U.S. cities.

${ }^{2}$ Interview with Michael Simmons (former Policy Director to Mayor of Chicago), Aug. 5, 2015.

${ }^{3}$ Interview with Karen Lehman (director, Fresh Taste funding collaborative), May 9, 2014.

${ }^{4}$ Interview with Sonya Harper (Executive Director, Growing Greater Englewood), July 30, 2015.

${ }^{5}$ Interview with Naomi Davis (Executive Director, Blacks In Green), June 11, 2014

${ }^{6}$ Erika Allen, remarks during community meeting at Altgeld Gardens, October 10,2014

${ }^{7}$ Interview with Anton Seals (Lead Steward, Grow Greater Englewood), September 17, 2014.

${ }^{8}$ Interview with Rebekah Silverman (Associate Director, Growing Home), July $15,2015$.

${ }^{9}$ A CLT, when applied to housing, is a nonprofit organization with two basic features. First, it splits ownership of homes and land. Residents own homes, but not the land underneath, which they lease from the trust. Home sales are price-restricted according to terms set by the ground lease. Second, CLTs typically have a tripartite board of directors: one third of seats for CLT residents; another third for neighboring residents; the rest for civic leaders.

${ }^{10}$ Ujamaa CLT, "Vision Statement." www.ujamaaclt.com (accessed July 6, 2018).

${ }^{11}$ Ujamaa CLT, "Our Principles," www.ujamaaclt.com (accessed July 20, 2018).

${ }^{12}$ Community organizing and community cohesion do not necessarily promote equality or justice (Sampson 2012, 45) - as when white neighborhood associations have violently excluded blacks. 
${ }^{13}$ Interview with Rebekah Silverman (Associate Director, Growing Home), July $15,2015$.

${ }^{14}$ Interview with Mary Jo Schnell (former Executive Director, NeighborSpace), Aug. 10, 2012.

${ }^{15}$ Interview with Ken Dunn (Executive Director, Resource Center), July 21, 2014.

${ }^{16}$ Interview with Brandon Johnson (former Executive Director, Washington Park Consortium), July 13, 2015.

${ }^{17}$ Ben Helphand, remarks during panel on "Establishing Long Term Land Management," Vacant Acres Symposium, New School For Social Research, April 23, 2014.

${ }^{18}$ Interview with Mary Jo Schnell.

${ }^{19}$ Interview with Harry Rhodes (Executive Director, Growing Home), June 4, 2014.

${ }^{20}$ Interview with Sonya Harper (Executive Director, Grow Greater Englewood), July 30, 2015. 


\section{REFERENCES}

Alexander, Gregory S., Eduardo M. Peñalver, Joseph William Singer, and Laura S. Underkuffler 2009 "A Statement of Progressive Property," Cornell Law Review 94: 743-744.

Allard, Scott W. and Mario L. Small. 2013. "Reconsidering the Urban Disadvantaged: The Role of Systems, Institutions, and Organizations." ANNALS of the American Academy of Political and Social Science 647: 620.

Anthony, Denise. 1997. "Micro-Lending Institutions: Using Social Networks to Create Productive Capabilities." International Journal of Sociology and Social Policy 17: 156-178.

Bell, Monica C. 2016. "Situational Trust: How Disadvantaged Mothers Reconceive Legal Cynicism," Law \& Society Review 50: 314-347.

. 2017. "Police Reform and the Dismantling of Legal Estrangement." Yale Law Journal 126: 2054-2150.

Berlant, Lauren. 2011. Cruel Optimism. Raleigh: Duke University Press.

Blauner, Robert. 1972. Racial Oppression in America. New York: Harper \& Row.

- 2001. Still the Big News: Racial Oppression in America. Philadelphia: Temple University Press.

Boaz, David. 2004. "Defining the Ownership Society." The Cato Institute, https://perma.cc/ER2M-UKAU (accessed Nov. 9, 2018).

Brooks, Richard R. W., and Carol M. 2013. Saving the Neighborhood: Racially Restrictive Covenants, Law, and Social Norms. Cambridge, MA: Harvard University Press.

Burawoy, Michael. 1974. "Race, Class, and Colonialism." Social and Economic Studies 23(4): 521-550. . 2003. "Revisits: An Outline of a Theory of Reflexive Ethnography." American Sociological Review 68: 645-679.

Burns, Rebecca. 2017. "The Infamous Practice of Contract Selling is Back in Chicago." Chicago Reader, March 1. https://perma.cc/YMY4-89YH (accessed Nov. 9, 2018).

Chu, Luisa. 2018. "Urban Farmers Forced Off Land Find New Ground to Grow." Chicago Tribune, July 17. https://perma.cc/BMW4-95GZ (accessed Nov. 9, 2018).

Cleaver, Eldridge. 1968. "The Land Question," Ramparts 6(9): 52.

Coates, Ta-Nehisi. 2014. "The Case for Reparations" The Atlantic, June 2014, https://perma.cc/GA5K-LAPV (accessed Nov. 9, 2018).

Cruse, Harold. (1968) 2009. "Behind the Black Power Slogan," in Harold Cruse, Rebellion or Revolution, 193-260. New York: Morrow.

de Soto, Hernando. 2000. The Mystery of Capital. London: Bantam. 
Desmond, Matthew. 2015. "Severe Deprivation in America: An Introduction." RSF: The Russell Sage Foundation Journal of the Social Sciences 1(1): 111. 2016. Evicted: Poverty and Profit in the American City. New York: Crown. di Robilant, Anna. 2014. "Property and Democratic Deliberation: The Numerus Clausus Principle and Democratic Experimentalism in Property Law," American Journal of Comparative Law 62: 367-416.

Du Bois, W.E.B. 1907. Economic Co-operation Among Negro Americans. Atlanta: Atlanta University Press.

Durkheim, Emile. (1893) 2013. The Division of Labor in Society. George Simpson, Trans. Digireads.com

Ewick, Patricia and Susan S. Silbey. 1998. The Common Place of Law: Stories from Everyday Life. Chicago: University of Chicago Press.

Fanon, Frantz. (1961) 2004. The Wretched of the Earth. New York: Grove.

Flyvberg, Bent. 2006. "Five Misunderstandings About Case-Study Research." Qualitative Inquiry 12: 219-245.

Gray, Karen. 2008. "Community Land Trusts in the United States." Journal of Community Practice 16(1): 65-78.

Guarino, Mark. 2013. "Can This Chicago Community Be Saved? Hope Rises in Englewood." Christian Science Monitor, September 22, https://perma.cc/Y8LG-YB9C (accessed Nov. 9, 2018).

Hale, Robert Lee. 1923. "Coercion and Distribution in a Supposedly Non-Coercive State," Political Science Quarterly 38: 470-478.

Harris, Angela I. 1993. "Whiteness as Property," Harvard Law Review 106: 17071791.

Jefferson, Aisha I. 2009. "Urban Farmer Promotes Sustainable Living," Black Enterprise, May 14. https://perma.cc/3VAP-KXSR (accessed Nov. 9, 2018).

Karenga, Maulana. 2008. Kwanzaa: A Celebration of Family, Community and Culture. Los Angeles: University of Sankore Press.

Kirk, David S. 2016. "Prisoner Reentry and the Reproduction of Legal Cynicism," Social Problems 63(2): 222-243.

Kirk, David S. and Mauri Matsuda. 2011. "Legal Cynicism, Collective Efficacy, and the Ecology of Arrest." Criminology 49(2): 443-472.

Kirk, David S. and Andrew V. Papachristos. 2011. "Cultural Mechanisms and the Persistence of Neighborhood Violence" American Journal of Sociology 116: 1190-1233.

Levine, Jeremy R. 2017. "The Paradox of Community Power: Cultural Processes and Elite Authority in Participatory Governance," Social Forces 95(3): 1155-1179. 
Marwell, Nicole P. and Michael McQuarrie. 2013. "People, Place, and System: Organizations and the Renewal of Urban Social Theory." ANNALS of the American Academy of Political and Social Science 647: 126-143.

McElhattan, David, Laura Beth Neilsen, and Jill D. Weinberg. 2017. "Race and Determinations of Discrimination: Vigilance, Cynicism, Skepticism, and Attitudes about Legal Mobilization in Employment Civil Rights." Law \& Society Review 51(3): 669-703.

McKittrick, Katherine. 2013. "Plantation Futures," Small Axe 17(3): 1-15.

Mosse, David. 2006. "Anti-Social Anthropology? Objectivity, Objection, and the Ethnography of Public Policy and Professional Communities." Journal of the Royal Anthropological Institute 12: 935-956.

Nembhard, Jessica Gordon. 2014. Collective Courage: A History of African American Cooperative Economic Thought and Practice. University Park, PA: Pennsylvania State University Press.

North, Douglass. C. 1991. "Institutions." Journal of Economic Perspectives 5: 97112.

Omi, Michael, and Howard Winant. 2015. Racial Formation in the United States. 3rd Ed. New York: Routledge.

Raudenbush, Stephen W., and Robert J. Sampson. 2002. "Ecometrics: Toward a Science of Assessing Ecological Settings, With Application to the Systematic Social Observation of Neighborhoods." Sociological Methodology 29(1): 1-41.

Rosenberg, Greg, and Jeffrey Yuen. 2012. "Beyond Housing: Urban Agriculture and Commercial Development by Community Land Trusts," Lincoln Institute of Land Policy Working Paper WP13GR1.

Rosser, Ezra. 2013. "The Ambition and Transformative Potential of Progressive Property," California Law Review 101: 107-171.

Rothstein, Richard. 2017. The Color of Law: A Forgotten History of How Our Government Segregated America. New York: Liveright.

Ryo, Emily. 2016. "Legal Attitudes of Immigrant Detainees." Law \& Society Review 51: 99-131.

Safransky, Sara. 2014. "Greening the urban frontier: Race, property, and resettlement in Detroit." Geoforum 56: 237-248.

Sampson, Robert J. 2012. Great American City: Chicago and the Enduring Neighborhood Effect. Chicago: University of Chicago Press.

Sampson, Robert J., and Dawn Jeglum Bartusch. 1998. "Legal Cynicism and (Subcultural?) Tolerance of Deviance: The Neighborhood Context of Racial Differences," Law \& Society Review 32(4): 777-804.

Sampson, Robert J., Stephen W. Raudenbusch, and Felton Earls. 1997. "Neighborhoods and Violent Crime: A Multilevel Study of Collective Efficacy," Science 277: 918-924. 
Sanyal, Paromita. 2014. Credit to Capabilities: A Sociological Study of Microcredit Groups in India. Cambridge: Cambridge University Press.

Satter, Beryl. 2009. Family Properties: Race, Real Estate, and the Exploitation of Black Urban America. New York: Metropolitan.

Singer, Joseph. 2014. "Property as the Law of Democracy." Duke Law Journal 63: 1287-1335.

Small, Mario Luis. 2007. "Is There Such a Thing as 'The Ghetto'?” City 11(3): 413-421.

Small, Mario Luis, and Katherine Newman. 2001. "Urban Poverty after The Truly Disadvantaged: The Rediscovery of the Family, the Neighborhood, and Culture." Annual Review of Sociology 27: 23-45.

Smith, Henry E. 2012. "Property as the law of things." Harvard Law Review 125(7): 1691-1726.

Soss, Joe, and Velsa Weaver. 2017. "Police Are Our Government: Politics, Political Science, and the Policing of Race-Class Subjugated Communities." Annual Review of Political Science 20: 565-591.

Stoecker, Randy. 1991. "Evaluating and Rethinking the Case Study." The Sociological Review 39(1): 88-112.

Teamwork Englewood and LISC Chicago. 2005. "Englewood: Making a Difference." https://perma.cc/B86Q-MUEC (accessed Nov. 9, 2018).

Tyler, Tom R., Philip Atiba Goff, and Robert J. MacCoun. 2015. "The Impact of Psychological Science on Policing in the United States: Procedural Justice, Legitimacy, and Effective Law Enforcement." Psychological Science in the Public Interest 16(3): 75-109.

Urban Farm Pathways Project. 2015. "Englewood Community Farms Prospectus and Business Plan.” https://perma.cc/DF2R-BB4A (accessed Nov. 9, 2018)

Walton, Emily. 2016. 'It's Not Just a Bunch of Buildings': Social Psychological Investment, Sense of Community, and Collective Efficacy in a Multi-Ethnic Low-Income Neighborhood." City \& Community 15(3): 231-263.

White, Monica M. 2017. "'A Pig and a Garden': Fannie Lou Hamer and the Freedom Farms Cooperative." Food and Foodways 25(1): 20-39.

Wilson, William Julius. 1996. When Work Disappears: The World of the New Urban Poor. New York: Knopf. 